\title{
EFFECT OF NANOFLUID ON FRICTION FACTOR OF PIPE AND PIPE FITTINGS: PART II EFFECT OF COPPER OXIDE NANOFLUID
}

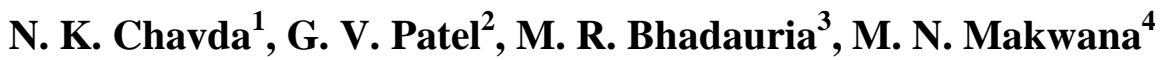 \\ ${ }^{1}$ Associate Professor, Department of Mechanical Engineering, A. D. Patel Institute of Technology, New Vallabh \\ Vidyanagar-388 121 \\ ${ }^{2}$ Assistant Professor, Department of Mechanical Engineering, A. D. Patel Institute of Technology, New Vallabh \\ Vidyanagar - 388121 . \\ ${ }^{3}$ Assistant Professor, Department of Mechanical Engineering, A. D. Patel Institute of Technology, New Vallabh \\ Vidyanagar - 388121 . \\ ${ }^{4}$ Assistant Professor, Department of Mechanical Engineering, A. D. Patel Institute of Technology, New Vallabh \\ Vidyanagar-388 121 .
}

\begin{abstract}
A nanofluid is prepared by mixing nano sized particles of size up to $100 \mathrm{~nm}$ and a base fluid. Commonly used nanoparticles are made of metals, oxides or carbides, while base fluids may be water, ethylene glycol or oil. Normally, the application of nanofluids is to enhance the heat transfer rate. Due to mixing of nanoparticles in the base fluid, the thermo-physical properties of the resulting mixture (base fluid + nanoparticles) changes. Therefore, resistance to flow of nanofluid increases which increases the friction factor and reduces the flow rate. In the part I of paper, an experimental investigation has been carried out to determine the effect of various concentration of $\mathrm{Al}_{2} \mathrm{O}_{3}$ nano-dispersion mixed in water as base fluid on Friction Factor of Pipe and Pipe Fittings. The present study deals with the effect of $\mathrm{CuO}$ nanofluid on the Friction Factor of Pipe and Pipe Fittings. The friction factor and loss coefficient of different pipes and pipe fittings increase with increase in volume concentration of CuO in water as compared to water.
\end{abstract}

Keywords: Nanofluid, Friction Factor, Pipe Friction, Pipe Fitting, CuO Nanoparticles.

\section{INTRODUCTION}

A nanofluid is a suspension of nano sized particles in a base fluid. Most commonly used nanoparticles are made of metals, oxides or carbides which are mixed with base fluids like water, ethylene glycol or oil. A nanofluid exhibits different thermo physical properties as compared to the base fluid. Commonly thermal conductivity of nanofluids is higher than the base fluid which increases the heat transfer rate. The increase in heat transfer rate mainly depends on type of nanoparticles, size of nanoparticles, shape of nanoparticles, type of base fluid and concentration of nanoparticles in base fluid.

There are two types of head loss during fluid flow viz. (1) Major Head Loss and (2) Minor Head Loss. Major head loss is due to friction during the fluid flow while minor head loss is due to disturbance in fluid flow pattern during the flow of fluid through sudden enlargement, sudden concentration, bend, elbow etc. When the nanofluid is flowing through the pipe, it offers more resistance to fluid flow due to friction. Many researchers have studied numerically and experimentally the phenomenon of effect of nanofluid on friction factor. The studies reported recently in literatures have been referred and presented here.

Chavda N. K. et. al. [1] have carried out experimental investigation to determine the effect of various concentration of $\mathrm{Al}_{2} \mathrm{O}_{3}$ nano-dispersion mixed in water as base fluid in the part I of the paper. They have employed volume concentrations of $\mathrm{Al}_{2} \mathrm{O}_{3}$ nanofluid $0.001 \%, 0.002 \%$, $0.003 \%$ and $0.004 \%$. They have found that friction factor and loss coefficient of different pipes and pipe fittings increase with increase in volume concentration of $\mathrm{Al}_{2} \mathrm{O}_{3}$ nano-dispersion compared to water.

Akhavan-Behabadi M. A. et.al. [2] have investigated the convective heat transfer of the heat transfer oil-copper oxide nanofluid flow in horizontal smooth and microfin tubes experimentally. They have used pure heat transfer oil and nanofluid with the weight concentrations of $0.5 \%, 1 \%$ and $1.5 \%$ as working fluids. They reported that combining use of nanoparticles and the microfin tube leads to the heat transfer enhancement up to $230 \%$, in comparison with the base fluid flow in the smooth tube. Rimbault B. et. al. [3] have presented an experimental investigation of the hydraulic and thermal fields of a $29 \mathrm{~nm} \mathrm{CuO}$ nanoparticle-water nanofluid with various volume fractions, $0.24 \%, 1.03 \%$ and $4.5 \%$ flowing inside a rectangular microchannel heat sink under both laminar and turbulent conditions. For a given fluid flow rate, experimental results show an increase of the pressure drop and the friction factor with respect to water along with slight heat transfer enhancement with respect to water for nanofluids with low particle volume fractions, $0.24 \%$ and $1.03 \%$, while for the $4.5 \%$ fraction a clear decrease of heat transfer was found. 
Chandrasekaran P. et. al. [4] have investigated the solidification characteristics of water based NFPCM (nanofluid phase change material) prepared by dispersing copper oxide nanoparticles and a nucleating agent in the base PCM (phase change material). They have found from the experimental results that considerable energy saving potential is possible. Nabeel Rashin M. and Hemalatha J. [5] have evaluated viscosity of novel coconut oil based copper oxide nanofluids of various concentrations prepared by ultrasonically assisted two step method theoretically and experimentally. They have propsed new empirical correlations for predicting viscosity of $\mathrm{CuO}$-coconut oil nanofluid at various temperatures and concentrations.

Kole M. and Dey T. K. [6] have reported the study related to effect of aggregation on the viscosity of copper oxide-gear oil nanofluids. They reported that viscosity of the nanofluids enhance by near about 3 times of the base fluid with $\mathrm{CuO}$ volume fraction of 0.025 , while it decreases significantly with the rise of temperature. Suresh S. et. al. [7] have compared the thermal performance of helical screw tape inserts in laminar flow of $\mathrm{Al}_{2} \mathrm{O}_{3}$ /water and $\mathrm{CuO}$ /water nanofluids through a straight circular duct with constant heat flux boundary condition. They reported that thermal performance factor of helical screw tape inserts using $\mathrm{CuO} /$ water nanofluid is found to be higher when compared with the corresponding value using $\mathrm{Al}_{2} \mathrm{O}_{3}$ /water. Chang $\mathrm{M}$. H. et. al. [8] have reported the procedure to prepare $\mathrm{CuO}_{-}$ water nanofluid for enhancing the thermal conductivity using various $\mathrm{CuO}$ contents and surfactant concentrations.

The investigations reported in the literatures are related to the friction factor phenomenon of the nanofluid along with the heat transfer characteristics for particular application using different nanofluids. The separate study related to the effect of nanofluid in pipe and pipe fittings are not presented in open literature.

In order to evaluate the effect of nanofluid in pipe and pipe fittings separately rather than considering along with heat transfer characteristics for a particular application, separate experimentations need to be carried out. Therefore, the effect of nanofluid prepared by dispersing $\mathrm{Al}_{2} \mathrm{O}_{3}$ nanodispersion in water in different volume concentration on friction factor of pipe and pipe fittings have been evaluated experimentally in the part I of the paper and the same of $\mathrm{CuO}$ nanoparticles have been evaluated in the paper.

\section{EXPERIMENTAL SETUP AND PROCEDURE}

Two experimental setups viz. (1) Apparatus for Pipe Friction and (2) Apparatus for Pipe Fittings are required to evaluate the effect of nanofluid on friction factor of pipe and pipe fittings experimentally. Detailed specifications and procedure for experimentation are exactly same as reported in part I of the paper.

\section{PREPARATION OF NANOFLUID}

Two techniques are used to make nanofluids viz. (1) the single-step direct evaporation method, which simultaneously makes and disperses the nanoparticles directly into the base fluids and (2) the two-step method which first makes nanoparticles and then disperses them into the base fluids. In either case, a well-mixed and uniformly dispersed nanofluid is needed for successful reproduction of properties and interpretation of experimental data. For nanofluids prepared by the two-step method, dispersion techniques such as high shear and ultrasound can be used to create various particle/fluid combinations.

Two-step method has been employed to prepare nanofluid. $\mathrm{CuO}$ nanoparticles have been purchased from $\mathrm{M} / \mathrm{s}$. Jyotirmay Overseas, Rajkot. $\mathrm{CuO}$ nanoparticles are of 40 $\mathrm{nm}$ size has $6310 \mathrm{~kg} / \mathrm{m}^{3}$ density. The proportion of $\mathrm{CuO}$ nanoparticles to be mixed with base fluid i.e. water for different volume concentration is calculated using equation number 1 and density of nanofluid is calculated using equation number 2 . For different volume concentrations, the mass of nanoparticle to mix with the water is presented in Table 1. The $\mathrm{CuO}$ nanofluid prepared is shown in Figure 1.

$$
\begin{gathered}
\phi=\frac{\frac{w_{\text {nanoparticle }}}{\text { Pnanoparticle }^{\text {manoparticle }}+W_{\text {Water }}}}{\text { Pnanoparticle }_{\text {Pwater }}} \times 100 \\
\rho_{\text {nanofluid }}=\phi \rho_{\text {nanoparticle }}+(1-\phi) \rho_{\text {wwater }}
\end{gathered}
$$

Table 1: Mass of CuO Nanoparticles to Mix with the Water for Different Volume Concentration

\begin{tabular}{|l|l|l|l|l|}
\hline $\begin{array}{l}\text { Volume } \\
\text { Concentration, } \\
\varphi\end{array}$ & $\begin{array}{l}0.001 \\
\%\end{array}$ & $\begin{array}{l}0.002 \\
\%\end{array}$ & $\begin{array}{l}0.003 \\
\%\end{array}$ & $0.004 \%$ \\
\hline Case Number & Case B & Case C & Case D & Case E \\
\hline $\begin{array}{l}\text { Mass of CuO } \\
\text { Nanoparticles } \\
\text { to be mixed } \\
\text { with water in } \\
\text { grams }\end{array}$ & 10.73 & 21.45 & 32.18 & 42.91 \\
\hline $\begin{array}{l}\text { Quantity of } \\
\text { Base Fluid i.e. } \\
\text { Water in litres }\end{array}$ & 170 & 170 & 170 & 170 \\
\hline
\end{tabular}

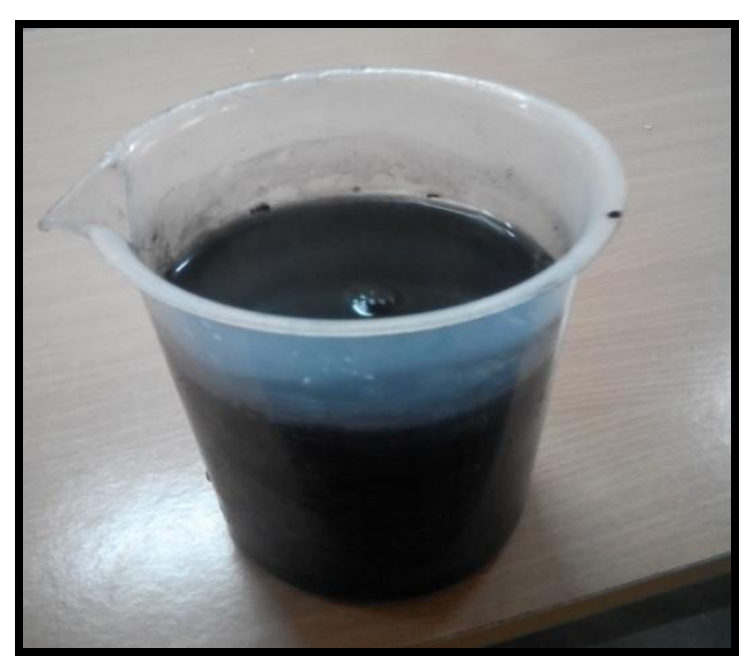

Fig. 1: CuO Nanofluid 


\section{INTEGRATED RESEARCH METHODOLOGY}

The integrated methodology adopted to evaluate the effect of nanofluid in friction factor of different types of pipe and pipe fittings are as under.

(1) Fill the water in apparatus for pipe friction and conduct the tests as per the experimental procedure for pipe friction. This is termed as Case A.

(2) Calculate the friction factor for different types of pipes as per the calculation steps for pipe friction for water.

(3) Empty the water from the tank of apparatus for pipe friction.

(4) Fill the water in apparatus for pipe fittings and conduct the tests as per the experimental procedure for pipe four types of fittings one by one. This is termed as Case A.

(5) Calculate the loss coefficient for different types of pipe fittings as per the calculation steps for four types of pipe fittings for water.

(6) Empty the water from the tank of apparatus for pipe fitting.

(7) For Case B, prepare the nanofluid by mixing 10.73 grams of $\mathrm{CuO}$ nanoparticles in water of 170 liters.

(8) Perform the experimentation for Case B as per the step number 1 to 6 of integrated research methodology.

(9) Perform the experimentation for Case C, Case D and Case $E$ as per the step number 1 to 6 of integrated research methodology.

(10) Compare the results.

\section{RESULTS AND DISCUSSION}

Actual experimentation on apparatus of pipe friction and pipe fittings has been carried out as per integrated research methodology. The results for pipe friction and pipe fittings are tabulated in Table No. 2 and 3 respectively and represented graphically in Figure No. 2 and 3 respectively.

Table -2: Result for Pipe Friction

\begin{tabular}{|l|l|l|l|l|l|}
\hline Sr. & Case & \multicolumn{3}{|l|}{ Friction factor } \\
\cline { 3 - 7 } No & No. & $\begin{array}{l}\text { GI Pipe } \\
\text { of } 17\end{array}$ & $\begin{array}{l}\text { GI Pipe } \\
\text { of 21 } \\
\text { mm }\end{array}$ & $\begin{array}{l}\text { Cu Pipe } \\
\text { of 14.5 } \\
\text { mm }\end{array}$ & $\begin{array}{l}\text { Al Pipe } \\
\text { of 12.5 } \\
\text { mm } \\
\end{array}$ \\
& & $\begin{array}{l}\text { mm } \\
\text { Inside } \\
\text { Dia. }\end{array}$ & $\begin{array}{l}\text { Inside } \\
\text { Dia. }\end{array}$ & $\begin{array}{l}\text { Inside } \\
\text { Dia. }\end{array}$ & $\begin{array}{l}\text { Inside } \\
\text { Dia. }\end{array}$ \\
\cline { 3 - 7 } & & Pipe A & Pipe B & Pipe C & Pipe D \\
\hline 1 & A & 0.04295 & 0.02423 & 0.02280 & 0.01215 \\
\hline 2 & B & 0.04844 & 0.02696 & 0.02622 & 0.01354 \\
\hline 3 & C & 0.04882 & 0.02822 & 0.02682 & 0.01385 \\
\hline 4 & D & 0.05772 & 0.03117 & 0.02826 & 0.01409 \\
\hline 5 & E & 0.05897 & 0.0339 & 0.02977 & 0.01463 \\
\hline
\end{tabular}

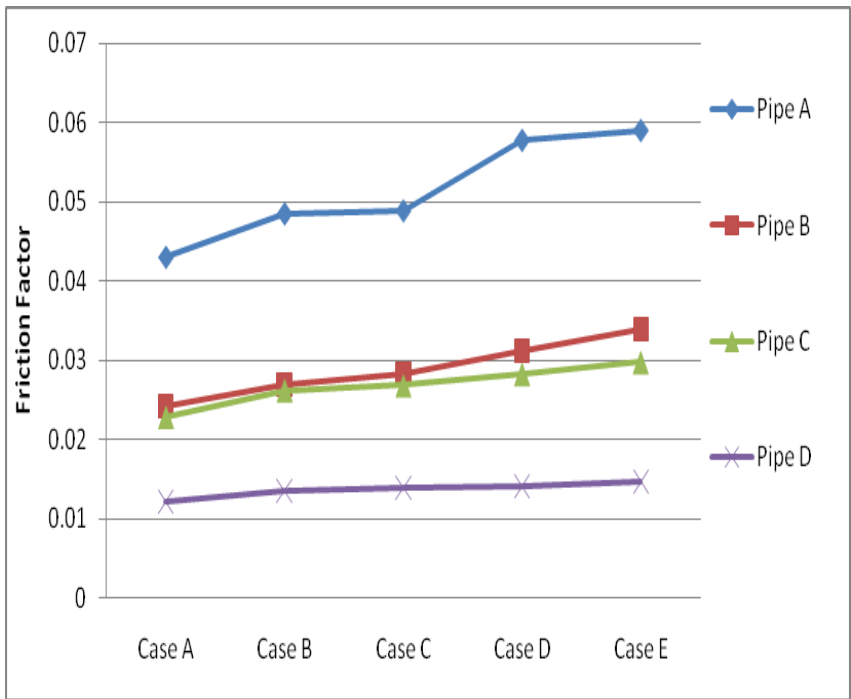

Fig.2: Result of Pipe Friction

The value of friction factor for different pipes increases with increase in volume concentration of $\mathrm{CuO}$ nano-particles in water. The maximum increase in friction factor for G.I. pipe having $17 \mathrm{~mm}$ inside diameter, G. I. pipe having $21 \mathrm{~mm}$ inside diameter, Copper pipe having $14.5 \mathrm{~mm}$ inside diameter and Aluminum pipe having $12.5 \mathrm{~mm}$ inside diameter for $0.004 \% \mathrm{CuO}$ nanofluid is $37 \%, 40 \%, 31 \%$ and $20 \%$ respectively compared to base fluid i.e. water.

Table -3: Result for Pipe Fittings

\begin{tabular}{|c|c|c|c|c|c|}
\hline \multirow{2}{*}{$\begin{array}{l}\mathrm{Sr} \\
\text { No }\end{array}$} & \multirow{2}{*}{$\begin{array}{l}\text { Case } \\
\text { No. }\end{array}$} & \multicolumn{4}{|c|}{ Loss Coefficient } \\
\hline & & $\begin{array}{l}3 \\
0 \\
0 \\
\underline{\underline{I}}\end{array}$ & $\begin{array}{l}\vec{E} \\
\text { D. } \\
\stackrel{0}{0}\end{array}$ & 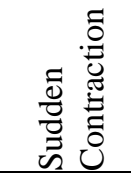 & 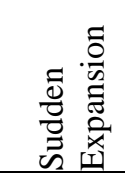 \\
\hline 1 & $\mathrm{~A}$ & 1.50623 & 1.58946 & 0.52477 & 0.12392 \\
\hline 2 & $\mathrm{~B}$ & 1.81570 & 1.60687 & 0.54164 & 0.12639 \\
\hline 3 & $\mathrm{C}$ & 2.14890 & 1.69457 & 0.64801 & 0.12654 \\
\hline 4 & $\mathrm{D}$ & 2.48980 & 1.75489 & 0.65890 & 0.13165 \\
\hline 5 & $\mathrm{E}$ & 2.55390 & 1.87774 & 0.71744 & 0.14125 \\
\hline
\end{tabular}

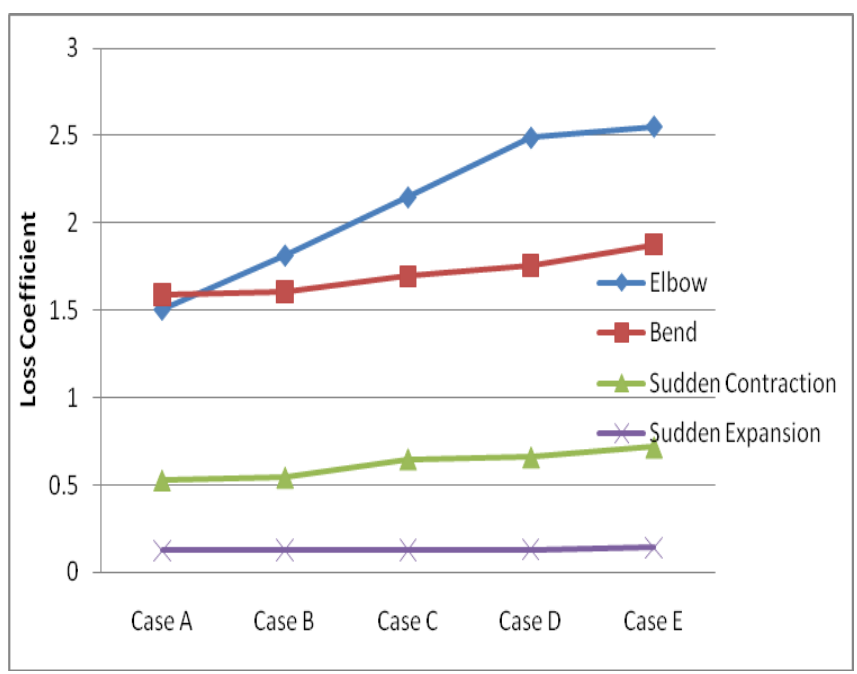

Fig.2: Result of Pipe Fitting 
The value of loss coefficient for different pipes fittings increases with increase in volume concentration of $\mathrm{CuO}$ nano-particles in water. The maximum increase in loss coefficient for elbow, bend, sudden concentration, sudden expansion for $0.004 \% \mathrm{CuO}$ nanofluid is $69 \%, 18 \%, 37 \%$ and $14 \%$ respectively compared to base fluid i.e. water.

\section{CONCLUSION}

An experimental investigation is carried out to determine the effect of various concentration of $\mathrm{CuO}$ nano-particles mixed in water as base fluid. The volume concentrations of $\mathrm{CuO}$ nanofluid prepared are $0.001 \%, 0.002 \%, 0.003 \%$ and $0.004 \%$. The conclusion derived for the study is that friction factor and loss coefficient of different pipes and pipe fittings increase with increase in volume concentration of $\mathrm{CuO}$ nano-particles as compared to water.

\section{ACKNOWLEDGEMENTS}

The authors are extremely thankful to the staff members of Mechanical Engineering Department, A. D. Patel Institute of Technology, New Vallabh Vidyanagar for providing the useful resources and the management of the college and Charutar Vidya Mandal for providing financial support to carry out the experimentation work. The authors are also thankful to Janak P. Jani, Arpit K. Patel, Kuldeep P. Zala and Nikunj G. Nimbark and other students of the college for providing their untiring support and efforts wherever needed.

\section{REFERENCES}

[1] N. K. Chavda, Janak P. Jani, Arpit K. Patel, Kuldeep P. Zala and Nikunj G. Nimbark, Effect of Nanofluid on Friction Factor of Pipe and Pipe Fittings: Part I Effect of Aluminum Oxide Nanofluid, International Journal of Current Engineering and Technology, Vol.4, No.6 (Dec 2014), pp. 4069-4074.

[2] M. A. Akhavan-Behabadi, F. Hekmatipour, S.M. Mirhabibi and B. Sajadi, An empirical study on heat transfer and pressure drop properties of heat transfer oil-copper oxide nanofluid in microfin tubes,International Communications in Heat and Mass Transfer, Volume 57, October 2014, pp. 150156.

[3] Benjamin Rimbault, Cong Tam Nguyen and Nicolas Galanis, Experimental investigation of $\mathrm{CuO}-$ water nanofluid flow and heat transfer inside a microchannel heat sink, International Journal of Thermal Sciences, Volume 84, October 2014, pp. 275-292.

[4] P. Chandrasekaran, M. Cheralathan, V. Kumaresan \& R. Velraj, Enhanced heat transfer characteristics of water based copper oxide nanofluid PCM in a spherical capsule during solidification for energy efficient cool thermal storage system, Energy, Volume 72, 1 August 2014, pp. 636-642.
[5] M. Nabeel Rashin, J. Hemalatha, Viscosity studies on novel copper oxide-coconut oil nanofluid, Experimental Thermal and Fluid Science, Volume 48, July 2013, pp 67-72.

[6] Madhusree Kole and T.K. Dey, Effect of aggregation on the viscosity of copper oxide-gear oil nanofluids, International Journal of Thermal Sciences, Volume 50, Issue 9, September 2011, pp. 1741-1747.

[7] S. Suresh, K. P. Venkitaraj \& P. Selvakumar, Comparative study on thermal performance of helical screw tape inserts in laminar flow using $\mathrm{Al}_{2} \mathrm{O}_{3}$ /water \& $\mathrm{CuO} /$ water nanofluids, Superlattices \& Microstructures, Volume 49, Issue 6, June 2011, pp. 608-622.

[8] Ming-Hui Chang, Hwai-Shen Liu, Clifford Y. Tai, Preparation of copper oxide nanoparticles and its application in nanofluid, Powder Technology, Volume 207, Issues 1-3, 15 February 2011, pp. 378386.

\section{BIOGRAPHIES}

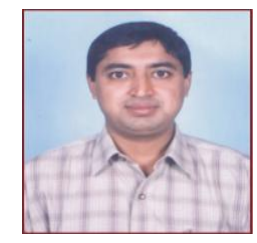

Dr. N. K. Chavda has completed M. E. (Mech) from SVNIT, Surat and Ph. D. from The M. S. University of Baroda. He has 19 years of teaching experience and published many papers in International Journals/Conference. He has been awarded with "Best Polytechnic Teacher" by ISTE, New Delhi and "The Dronacharya Award", for the admirable contribution in teaching-learning and overall development of students adjudged by ADIT and CVM.

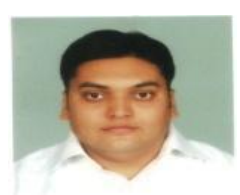

G. V. Patel accomplished his postgraduation with specialization in $\mathrm{CAD} / \mathrm{CAM}$ and having more than 6 years of teaching experience. $\mathrm{He}$ has presented/published number of papers in international \& national conferences \& Journals in the areas of CFD

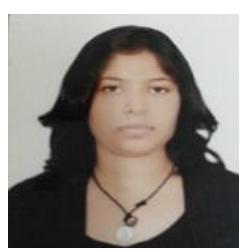

Ms. Madhuri Bhadauria completed her post-graduation with specialization in Thermal Engineering from Nirma University, Ahmedabad.

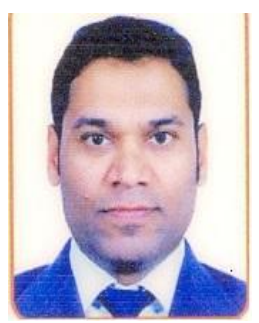

Prof. M.N Makwana accomplished his post-graduation from the MSU, Vadodara with specialization in Jet Propulsion and gas Turbine Plants and having more than 8 years of teaching experience. He has presented/published number of papers in international \& national conferences \& Journals in the areas of CFD, Nano fluid heat transfer, and Renewable Energy. 